\title{
QUALITY IMPROVEMENT MANAGEMENT LEARNING AT IT JUNIOR HIGH SCHOOL (SMP IT) AL KAFFAH BINJAI
}

\author{
Syafaruddin $^{1}$, Mesiono ${ }^{2}$, Asnawati ${ }^{3}$ \\ ${ }^{1}$ State Islamic University of North Sumatra, Medan, Indonesia \\ ${ }^{2}$ State Islamic University of North Sumatra, Medan, Indonesia \\ ${ }^{3}$ State Islamic University of North Sumatra, Medan, Indonesia \\ *Correspondence: asnawatii1234584@gmail.com
}

\begin{abstract}
This study is to analyze the management of improving the quality of learning at SMP IT Al Kaffah Binjai, from the aspects of planning, organizing, implementing and monitoring. This study uses a qualitative approach with descriptive analytical study method. Data collection was done through interviews, observation and documentation techniques. Data analysis was carried out through data reduction, data presentation, and data verification. The results of this study indicate that efforts to improve the quality of learning at SMP IT Al Kaffah are managed well and effectively. This is viewed from (1) planning, including the formation of a curriculum development team, managing learning activities according to the national education calendar, ensuring teachers create learning programs, planning for student recruitment preparations (new students or transfer students), school orientation and additional programs, and preparation learning planning documents; (2) organizing, including a structured delegation of school organization, starting from the founder delegating it to the foundation, the foundation delegating it to the principal, as well as the principal who is assisted by representatives, teachers and education staff; (3) implementation, including the process of interaction between teachers and students as well as learning facilities; and (4) supervision, including internal supervision (principal) and external supervision (supervisor from the Binjai City Education Office), which oversees the academic and managerial aspects of the school.
\end{abstract}

Keywords: Management, Learning, Quality Improvement.

\begin{abstract}
ABSTRAK
Penelitian ini untuk menganalisa manajemen peningkatan mutu pembelajaran di SMP IT Al Kaffah Binjai, dari aspek perencanaan, pengorganisasian, pelaksanaan dan pengawasan. Penelitian ini menggunakan pendekatan kualitatif dengan metode studi deskriptif analitik. Pemerolehan data dilakukan melalui teknik wawancara, observasi dan dokumentasi. Analisis data dilakukan melalui reduksi data, penyajian data, dan verifikasi data. Hasil penelitian ini menunjukkan bahwa upaya peningkatan mutu pembelajaran di SMP IT Al Kaffah dikelola dengan baik dan efektif. Hal ini ditinjau dari (1) perencanaan, meliputi pembentukan tim pengembang kurikulum, mengatur waktu kegiatan pembelajaran sesuai kalender pendidikan nasional, memastikan guru membuat program pembelajaran, perencanaan persiapan rekrutmen siswa (siswa baru atau siswa pindahan), orientasi sekolah dan program tambahan, dan persiapan dokumen perencanaan pembelajaran; (2) pengorganisasian, meliputi pelimpahan secara terstruktur tentang organisasi sekolah, mulai dari pendiri melimpahkan kepada pihak yayasan, pihak yayasan melimpahkan kepada kepala sekolah, begitu juga kepala sekolah yang dibantu oleh wakil, guru dan tenaga kependidikan; (3) pelaksanaan, meliputi proses interaksi antara, guru dan siswa serta fasilitas belajar; dan (4) pengawasan, meliputi supervisi internal (kepala sekolah) dan supervisi eksternal (pengawas dari Dinas Pendidikan Kota Binjai), yang mengawasi aspek akademik dan manajerial di sekolah.
\end{abstract}

Kata Kunci: Manajemen, Pembelajaran, Peningkatan Mutu. 


\section{A. PRELIMINARY}

The success of a country is determined by the quality of human resource factors. The human resource (HR) factor indicates high quality education when the quality of education in the country is high. The quality of education is one of the pillars of human resource development. Even the future of the nation lies in the existence and quality of education. National Education has a vision of realizing the education system as a strong and authoritative social institution to empower all Indonesian citizens to develop into quality human beings so that they are able and proactively respond to changing times. (Mulyasana, 2012: 11).

In addition, the quality of education is also influenced by very complex factors, these factors are an inseparable system. They are interconnected and support each other. Among the factors in question are educators, students, curriculum, facilities or means, methods, media and so on. Everything must be managed or managed as well as possible so that it can maximally help achieve quality and quality education (Alfiansyah, et.al., 2020: 52-67).

The above as expressed by Syafaruddin (2002: 19) that with the change in the new paradigm of education to quality (quality oriented) is one strategy to achieve the development of children's personal excellence. Quality education will only appear if there are educational institutions that really pay attention to the quality of education. The realization of superior quality education cannot be separated from the management of education, as expressed by Dryden \& Jeannette (2001: 408) that education must be managed in total (total quality management). So that quality and quality education cannot be separated from the quality of management or management that is carried out.

In line with this, Terry \& Reice (1996: 1) revealed that management is an activity to manage or regulate an activity to achieve goals. As for what is managed and regulated optimally are all facilities, facilities, and even human resources in achieving goals. As expressed by Fattah (2011: 3) that management is intended to achieve organizational goals by managing other people until management can also be interpreted as the art of getting work done through people.

The quality of education is not something that stands alone but is a unit that is interconnected and related as a process in a system. When talking about quality issues that are the subject and object of development that need to be improved in quality through education in its functions, processes, and activities which lead to the achievement of national 
education goals (Syafaruddin, 2002: 2; Syafaruddin, et.al., 2020).

Quality management in education is carried out by improving services to meet the wishes and expectations of customers. Customers in education are divided into three groups, namely: (1) students who directly receive services, (2) parents, or student sponsors who have a direct interest in individuals or institutions, (3) parties who have an important role, although not directly such as government and society as a whole (Sallish, 2010: 68; Assingkily \& Mesiono, 2019). The quality of Indonesian education is still far from expectations as expressed by Azra (2002: 13) that the achievement of national education is still far from expectations, let alone to compete competitively with the development of education at the global level.

Added Azra as quoted by Danim (2006: 4-6) that many people assume that Indonesian education not only has not succeeded in improving the intelligence and skills of students but has failed in shaping character and personality. This condition is seen from the role of schools as education providers which results in some parents feeling pessimistic about the role of schools or madrasas, there is also an assumption that schools or madrasas fail to build vertical mobility because schools or madrasas do not guarantee decent work.

This is what ultimately lies behind the establishment of an Integrated Islamic private school as a solution or a middle way to overcome the dilemma above. When Integrated Islamic Schools (IT) began to open even though their status was private schools, the attention of the community began to shift to these educational institutions. In fact, registration for these schools precedes state schools by going through a selection process due to their limited capacity. An integrated Islamic school in the view of parents is the answer that quality and character can be built simultaneously.

This is confirmed byAmrullah (2015: 171-185) that for parents, the emergence of Integrated Islamic Schools is like finding freshness in barren land, being aware of the need for religion as well as mastery of general knowledge plus a deep inability to Islamic knowledge makes the demand for sending their children to Islamic educational institutions such as this Integrated Islamic School very large. No matter the amount of money, the most important thing is that their children master general knowledge as well as master religion. But are these educational institutions really providing quality education? 
The Integrated Islamic School (SIT) is essentially an institution that implements the concept of Islamic education based on the Qur'an and Sunnah. The operational concept of an integrated Islamic school is an accumulation of a process of learning, civilizing, inheriting and developing Islamic teachings, Islamic culture and civilization from generation to generation.

In the Integrated Islamic School, it is emphasized that the integration in the methode learning so as to optimize the cognitive, affective and psychomotor as well as conative. The implications of this integration require the development of a learning process approach that is rich, varied and uses broad and flexible media and learning resources. The learning method emphasizes the use of a problem solving-based approach that trains students to think critically, systematically, logically, and solutively. Integrated Islamic schools also train their students with various kinds of creativity that train students to think original, flexible, fluent, and imaginative. Skills in carrying out various activities that are beneficial and full of benefits for themselves and their environment.

Integrated Islamic schools also combine aqliyah, ruhiyah and bodily education. This means that an integrated Islamic school seeks to educate its students to become children who develop intellectual and intellectual abilities, improve the quality of faith and devotion to Allah swt, develop noble character, have health and fitness, skills in daily life. The integrated Islamic school also combines the involvement and active participation of the learning environment, namely; school, home and community.

Basically the Integrated Islamic School was initiated because it saw the effect of national schools that educate secularistic children by separating religious life and social life in society. Then there are several Islamic schools which are also part of secularism which are very focused on continuing to carry out mahdah worship so that they ignore the side of science. This has an impact on Muslims who are increasingly slumped in the field of science and technology. In order to maintain the quality and quality of integrated Islamic schools, a number of practitioners and observers of Islamic education have formed a forum, namely the Integrated Islamic School Network (JSIT), with its main mission; Islamic, effective and quality (Amrullah, 2015).

In line with the noble goal of establishing an Integrated Islamic School, there must be weaknesses or shortcomings in practice. As Amrullah (2015: 181-183) analyze the shortcomings that exist in the Integrated Islamic School in practice The 
stigma of elite schools, and the weight of abundant material.

Seeing some of the advantages and advantages possessed by the Integrated Islamic School, it should be a reality, that Islamic educational institutions, actually have a role and opportunity to be superior, but with a note that they can minimize existing shortcomings and weaknesses so that they can truly excel and become " idol" for society. This certainly must be supported by the quality management of learning.

This research was conducted at SMP IT Al Kaffah Binjai under the auspices of the Al Kaffah Binjai Foundation. The results of initial observations about the quality management of learning in SMP IT Al Kaffah in Binjai can be said to be exclusive, because "general" educational institutions under the auspices of the Ministry of Education and Culture (Kemendikbud) with the national curriculum are also combined with independent curriculum, which is termed the muwashafat-based manhaj (MBM). As a ma'rifatullah-oriented school, this curriculum contains Islamic values to be inclusive which is the process of implementing direct learning in classroom teaching by instilling the basics of Islamic values to students so that in students a strong Islamic basis will be embedded, especially aqidah, morals, and the Koran in order to create quality educational institutions and answer the demands of society.

Moreover, judging by the background of the establishment of SMP IT Al Kaffah, it cannot be separated from the purpose of establishing the Al Kaffah foundation, namely to foster morals, and develop the potential of Muslims in the spirit of congregation to build an Islamic generation. The embodiment of this spirit is evidenced by the erection of permanent three-story school buildings that are also quite magnificent.

Even more interesting is the construction of buildings at this school, which was raised from funds from several waqf, community and foundation funds to buy the location which became the Islamic Center, build the building, and for other operational costs. So that school fees become relatively cheap, this is also based on the condition of the people of Binjai City who have difficulty obtaining quality education without having high costs, the small portion of time in the public school curriculum in providing Islamic religious learning and education, the weakness of school development on character learning. and noble character.

In addition, there is an education fund compensation (semester) to students who are unable but have a high willingness 
to learn (especially orphans) with an increase in the number of multiples of 12 children per year from Self-Help Foundation funds, Zakat, Infaq and Alms of the Muslims. Also to educators and coaches (Teachers Ngaji) in the villages.

IT Al Kaffah Junior High School itself only accepts 2 classes of students each year, one male class and one female class, this is intended so that the quality of learning can be maintained. Even though all of them are combined into 1 class, there is a separator between sons and daughters so that they do not mix between sons and daughters. Though the interest of parents to enroll their children in this school is very high.

This interest is based on the many achievements that students always get at the competition momentum at the subdistrict and city levels of Binjai. The achievements include the champion of futsal, archery, pencak silat tahfiz Qur'an, recitations and so on. In addition, the teachers who teach at SMP IT Al Kaffah Binjai also made many achievements in MTQ activities in North Binjai District to MTQ in Binjai City.

Quality improvement programs carried out at SMP IT Al Kaffah are not only carried out for students but also educators and education staff in improving their quality. The school facilitates with Al-Quran tadabur activities every Sunday
(Sunday) which is delivered directly by the founder of $\mathrm{Al}$ Kaffah. Departing and starting from this thought, an in-depth and systematic research is needed on how to improve the management of learning quality at SMP IT Al Kaffah Binjai.

\section{B. METHOD}

This study uses a qualitative approach with analytical descriptive method (Sugiyono, 2010). The focus of this research is on analyzing the management of improving the quality of learning at SMP IT Al Kaffah Binjai. Data was collected using participant observation techniques, interviews and document analysis. Furthermore, data analysis uses data reduction techniques, descriptive and narrative presentation of data, and drawing conclusions. The validity of the research data was tested through triangulation techniques. Triangulation is meant as a form of data collection, which is then compared between one data with other data (interviewing one informant, with other informants) (Creswell, 2009). In this context, 2 (two) aspects of triangulation are compared, namely methods and data sources.

\section{DISCUSSION RESULT}

\section{Planning for Quality Improvement of Learning at SMP IT Al Kaffah Binjai}


Planning activities become an urgent part of the management process as a first step (Nadlir, 2013; Nurlaila, 2018). This activity is a management process to direct and control the education unit in accordance with policies, goals, plans, and procedures for quality and sustainable achievements. The main purpose of quality improvement planning activities is to plan quality improvement at every stage of activities in schools, including input, process, output from school management (Prabowo, 2010).

$$
\text { According to the }
$$

information of the Head of SMP IT

Al Kaffah Binjai via interviews regarding planning for improving the quality of learning explained that:

"The quality improvement planning activities carried out at the Al Kaffah Binjai Islamic integrated junior high school are carried out based on the work of the School Development Team which previously worked to compare the conditions of education in schools so far with the expected conditions. With regard to quality improvement, this school has systematically planned quality assurance which has made a quality improvement plan in the school work plan. In planning to improve the quality of learning at the $\mathrm{Al}$ Kaffah Islamic Junior High School, I involved several components, namely: teachers, students, parents and school committees." (Results of interview with Mr. H. Hanafiah I, S.Pd., MM, January 5, 2021).

The above explanation, confirmed by the Deputy Head of SMP IT for Curriculum, explained that:

"Planning for improving the quality of learning is carried out every year in meetings. Planning is prepared based on the results of the evaluation conducted by the school development team. The team analyzed the implementation of the program that had been prepared in the previous year. Information from teachers, students, committees, and even parents of students is also used as input for planning. So that the planning that is prepared is comprehensive in accordance with shared desires and needs.(Results of interview with Mrs. Delina Anggraini, S.Pd., January 6, 2021).

The foundation also provided information related to planning for improving the quality of learning, it was said that: 
"The foundation continues to provide direction and guidance to all school principals for each level unit, including to junior high school principals, so that the quality of learning continues to be improved and developed by receiving input from teachers, students, parents, and the surrounding community. The more input the more things can be done." (Results of an interview with the Founder of the Al Kaffah Foundation, Ust. Zulkarnain Asri, February 14, 2021).

The results of the interviews above are confirmed by the documentation of the minutes of the school's meeting with parents about the coordination meeting regarding the implementation of learning at SMP IT Al Kaffah Binjai. From the documentation of the minutes of the meeting, it can be seen that there were about 25 participants, consisting of 5 from the school and 20 from the parents.

Based on the researcher's observations of documents in schools, it was revealed that the principal's work program document explained that curriculum planning began by forming a curriculum development team that used rules or regulations as a reference in the preparation of curriculum programs such as regulations on content standards, graduation standards, process standards, and assessment standard. The next activity related to the curriculum is arranging programs that refer to the educational calendar and then directing educators to develop learning programs that are socialized to students, parents or school committees.

The data obtained from the interviews above are confirmed by the existence of school documents that contain both co-curricular and extra-curricular school activities. Furthermore, the researchers made observations on the document, seen in the document written coaching activities for students that aim to help achieve learning and learning objectives. There are six basic coaching for students, namely leadership and national character, social skills, entrepreneurship, a healthy lifestyle, a lifestyle that likes to worship and is proud to be Muslim, interests and talents.

In addition, SMP IT Al Kaffah Binjai plans to develop standards for educators and education personnel based on the 
characteristics of integrated Islamic schools in general. By referring to the standard documents for educators and education above, the planning is prepared by analyzing the needs of educators, determining the needs of educators based on the number, type of work and qualifications. The division of tasks and workloads is the focus of empowering education personnel and self-development.

At the planning stage for educators and education personnel, the Principal practically explains:

"The educator needs planning team that has work in planning the needs of educators, they are the head of the foundation including the school committee and myself select the educators and then empower the educators by preparing the division of tasks and giving additional assignments. Educators are also given the opportunity to develop themselves through training facilitated by orders or provided by the school. Educators are also given awards at certain moments by the school based on their achievements in carrying out their duties. (Results of interview with $\mathrm{Mr} . \mathrm{H}$. Hanafiah I, S.Pd., MM, January 5, 2021).
With regard to the explanation above, the Al Kaffah waqf foundation provides an affirmation, as it is said that:

"We get the need for teacher acceptance from the data submitted by the school principal, which will then be decided at the foundation meeting. Likewise, the acceptance of new teachers is decided by the foundation, taking into account the results of the assessment of the principal and the committee. Meanwhile, the teachers who have taught at the $A l$ Kaffah waqf foundation are also given the widest possible opportunity to participate in selfdevelopment activities and skills. In fact, we also plan a budget for teachers participating in training that is relevant to improving the quality of learning. Although currently the foundation has not been able to plan financing for teachers who want to continue to the Bachelor or Masters level due to limited funds." (Results of an interview with the Founder of the Al Kaffah Foundation, Ust. Zulkarnain Asri, February 14, 2021).

One person who had received funding while attending the training said that:

"The foundation and the principal of the IT Al Kaffah Middle School do 
not prohibit teachers from participating in training activities or anything related to improving the quality or quality of educators, as long as these activities are suitable and appropriate to the skills and needs of the school. We have been given assistance with costs or transportation when participating in a training held by the Ministry of Religion of the city of Binjai." (Results of an interview with a tahfiz. Al-Quran teacher, $\mathrm{Mr}$. Azhari Ramadhan, 13 February 2021).

The integrated Islamic junior high school Al Kaffah Binjai also pays great attention to the aspects of facilities and infrastructure, this is what the researchers saw contained in the guidebook related to the facilities and infrastructure available at this school. In providing education in the field of facilities and infrastructure, SMP IT Al Kaffah Binjai refers to the regulation of the minister of national education number 24 of 2007 concerning the standard of facilities and infrastructure and also refers to the standards and characteristics of integrated Islamic schools in general.
Based on the results of the description above, it is understood that the planning for improving the quality of learning at SMP IT Al Kaffah Binjai includes 4 (four) aspects, namely, curriculum (curriculum development team, managing time according to the national education calendar and ensuring teachers prepare learning programs), student affairs (PPDB regulations, transfer students, MPLS activity committee and schedule, arrange extracurricular programs, BK services, and achievement coaching), educators/educational staff (formation of a team for planning needs for tendons, team for division of tasks for tendons, team for development of tendons, and rules for appreciating students who excel), and facilities/infrastructure (composing a master plan for facilities/infrastructure, needs for facilities/infrastructure, rules for using facilities/infrastructure, maintenance of facilities/infrastructure, drawing up plans for developing facilities/infrastructure). 
2. Organizing Learning Quality Improvement at SMP IT Al Kaffah Binjai

Organizing in improving the quality of learning at SMP IT Al Kaffah Binjai consists of: Founder/founder of the foundation, management of the foundation, school principal, Deputy Principal (curriculum, student affairs, facilities and infrastructure), teachers, administration, and participants educate. More can be seen in Figure 1.

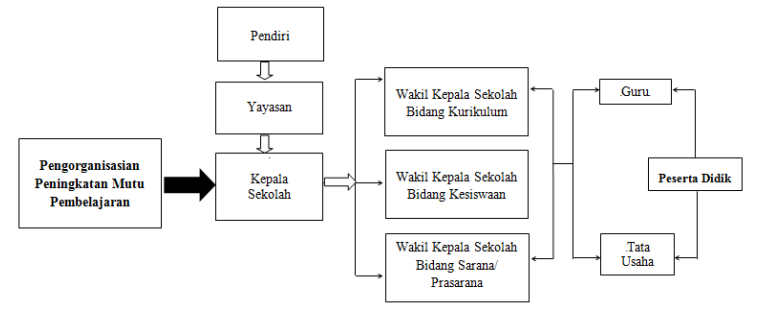

Figure 1. Organizational Structure of SMP IT Al Kaffah Binjai.

The founder / builder of the foundation is the person who from the beginning established and formed the foundation until now continues to manage waqf sourced from the community to become an Islamic center until the establishment of educational institutions and is responsible for continuing to develop it. Considering the wide range of fields developed by the Al Kaffah foundation, SMP IT Al Kafah is one part of that field. In organizing SMP IT Al Kaffah, the Founder of Al Kaffah formed the management of the foundation consisting of the Chairman of the Foundation who was assisted by the secretary of the foundation and the treasurer of the foundation.

Mr. Zulkarnain Asri, MA when confirmed regarding the organization of learning at SMP IT Al Kafah explained:

"Since the beginning of the establishment of the $A l$ Kaffah foundation, we have prepared a master plan in the form of goals, vision, mission and programs. Related to learning at SMP IT there are several programs such as curriculum, facilities and infrastructure, students, as well as educators and education staff. Organizing the curriculum, for example, this integrated Islamic program must be guided by basic ideals. There is another thing that is most important, organized from the start, namely the concept of learning that is integrated with Islamic values. This means that educators with whatever subjects they teach must be able to integrate with Islamic values.For facilities and infrastructure, there are permanent buildings with all adequate equipment, 


\begin{abstract}
only those required for maintenance and development are in accordance with accompanying needs. The student field stipulates that the input must be Muslim and able to read the holy verses of the Koran. These things that are fundamental about improving the quality of learning we coordinate with the foundation management to be carried out by the principal." (Results of an interview with the Founder of the Al Kaffah Foundation, Ust. Zulkarnain Asri, February 14, 2021).
\end{abstract}

This was emphasized by the principal, through interviews it was revealed that:

"With regard to improving the quality of learning from the aspect of teacher recruitment and education personnel, as well as general policies regarding the curriculum, namely subjects and extracurricular activities that must be based on Islamic values, as well as school facilities and infrastructure are at the discretion of the foundation. Meanwhile, I and the deputy heads of SMP IT Al Kaffah Binjai as managers have the task of compiling and perfecting the school's vision, content and goals, compiling the school's organizational structure, making medium and long-term work programs, making school regulations, and developing management information systems." (Results of interview with $M r . H$. Hanafiah I, S.Pd., MM, January 5, 2021).

The results of the interview were confirmed by the existence of a school principal's work program document that had been compiled and determined by the foundation, which included the duties of the deputy principals. Likewise, documentation of the organizational structure of SMP IT Al Kaffah Binjai.

Furthermore, the document was re-observed to reveal what the duties of the principal and deputy principal of SMP IT Al Kaffah Binjai were. In the document it is written that the principal in carrying out the task of leading the school is assisted by deputy principals in the fields of curriculum, student affairs and infrastructure. In the principal's work program document, it is explained that the principal's main tasks are 1) Develop and perfect the school's vision, content and goals, 2) develop the school organizational structure, 3) Prepare medium-term work plans and annual work plans, 4) Prepare 
school regulations, 5) develop a management information system.

\section{Implementation of Learning Quality} Improvement at SMP IT Al Kaffah Binjai

Implementation is the implementation of the planning stage (Rahayu \& Firmansyah, 2018). The implementation of improving the quality of learning is carried out by the Principal, Deputy Principal and teachers, taking into account the performance of each school member in an effort to improve the quality of learning. The implementation of learning at SMP IT Al Kaffah uses an integrated concept not by adding learning materials with Islamic materials such as monotheism, Islamic history and so on but combining these values in every lesson so that students are expected to achieve complete intelligence, namely spiritual intelligence, intellectual intelligence. , social and kinesthetic results from thinking, feeling, heart and sports. This is what Lubis, et.al. (2020), as an alternative in supporting development for children (students).
The principal when interviewed regarding the implementation of improving the quality of learning explained as follows:

"What I said earlier, starting from planning, organizing and now the systematic implementation of quality improvement management, there are several components that need to be observed. For the curriculum we carry out every year the development of curriculum documents such as revising the curriculum, SKL, SI, process standards and assessment standards and then socializing them to teachers to be implemented in the learning process. Some of the documents that we make are like the school calendar and learning schedule along with the division of tasks. For the student field, it is to prepare regulations regarding the acceptance of new students and also to carry out the acceptance of new students. The next step is to prepare for the introduction to the school environment and carry out these activities with teachers and student council administrators. Next is extracurricular activities by giving SK to competent teachers. Likewise for educators and education staff, the implementation is by selecting and assigning tasks according to their 
competence and there is a certain momentum we give them awards. And what is no less important is for facilities and infrastructure to ensure that they are in a suitable condition for use and to see the possibility of improving facilities and infrastructure according to the need to improve the quality of learning." (Results of interview with Mr. H. Hanafiah I, S.Pd., MM, January 5, 2021). Likewise for educators and education staff, the implementation is by selecting and assigning tasks according to their competence and there is a certain momentum we give them awards. And what is no less important is for facilities and infrastructure to ensure that they are in a suitable condition for use and to see the possibility of improving facilities and infrastructure according to the need to improve the quality of learning." (Results of interview with Mr. H. Hanafiah I, S.Pd., MM, January 5, 2021). Likewise for educators and education staff, the implementation is by selecting and assigning tasks according to their competence and there is a certain momentum we give them awards. And what is no less important is for facilities and infrastructure to ensure that they are in a suitable condition for use and to see the possibility of improving facilities and infrastructure according to the need to improve the quality of learning." (Results of interview with Mr. H. Hanafiah I, S.Pd., MM, January 5, 2021).

Strengthened by the statement of the Deputy Principal for curriculum related to the implementation of improving the quality of learning, it is said that:

"Before the new teaching, the thing I have to complete is mapping or dividing study groups. Based on the standard process, the maximum number of groups for junior high school is 32 people. That the number of students in class VII is 60 people consisting of 29 men and 31 women for the male group called class $A$ and the female class is class $B$. Actually this class is separate but due to the lack of classes, the learning process is carried out in a separate class. one class by limiting it with the hijab. Next, arrange lesson schedules and ensure planning and implementation as well as assessment of learning outcomes to supervisory activities. The dominant target of this activity is the teacher. So from planning to assessment of teachers who implement it in the implementation of learning " (Results of interview with Mrs. Delina Anggraini, S.Pd., January 6, 2021). 
In the school quality improvement document, the implementation of the curriculum component is part of the work program of the Principal of SMP IT Al Kaffah Binjai. In practice, the principal is assisted by the Deputy Principal in the fields of curriculum, students and infrastructure, while the teacher is the one who implements the quality improvement of learning in the classroom. The results of the interviews above are also supported by documentation in the form of a Learning Implementation Plan (RPP) compiled by teachers of SMP IT Al Kaffah Binjai, which contains the planting of Islamic values in learning even though these subjects are general in nature.

Furthermore, the implementation of improving the quality of learning at SMP IT Al Kaffah Binjai can be observed in Figure 2.

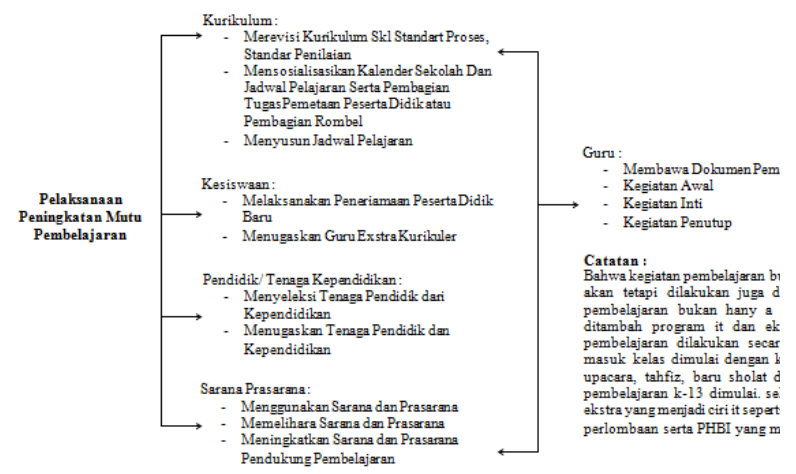

Figure 2. Concept Map of Implementation of Learning Quality Improvement in SMP IT Al Kaffah

Associated with improving the quality of learning, the implementation is a series of inputs, processes and outputs. SMP IT Al Kaffah Binjai stipulates that graduates have competence in the dimensions of attitude, knowledge and skills in accordance with the SKL document based on the 2013 curriculum. In addition, graduation standards are also determined by an integrated Islamic program, namely straight aqidah, noble character, memorizing and understanding the Koran, active and worship properly and preserve the environment.

\section{Supervision of Learning Quality} Improvement at SMP IT Al Kaffah Binjai

Supervisor is an important factor in the development of educational institutions. Without a supervisor, the learning process will run as it is and slow down the growth and development of an educational institution (Darussalam, 2020; Asmara \& Nindianti, 2019). Learning activities are not only the process 
of compiling documents, but must appear in thea learning process.

Regarding supervision in this study, the researcher conducted several interviews with the most competent parties to oversee the quality of learning at SMP IT Al Kaffah Binjai, namely the principal and several deputy principals who helped the supervision process to improve the quality of learning.

Supervision of improving the quality of learning at SMP IT Al Kaffah Binjai, carried out in a hierarchical manner, that every school must have an education supervisor assigned by the education office, including at SMP IT Al Kaffah Binjai. Likewise, because SMP IT Al Kaffah Binjai is a private school managed by a foundation, supervision is also carried out by the foundation as the founder or owner of this school.

This was explained by the Principal of SMP IT Al Kaffah Binjai when interviewed, saying that:

"There are several strategic things that are part of improving the quality of learning that I have to monitor carefully, namely the curriculum, student affairs, educators and educational staff. In the field of curriculum that is supervised is the process of implementing the curriculum starting from supervising the process of preparing the educational calendar, supervising the implementation of learning programs. In the field of student affairs supervised is the acceptance of new students, supervising the implementation of the introduction of the school environment and supervising the implementation of extracurricular activities. In the field of educators and education, it cannot be separated from the supervision of the principal as the full person in charge of implementing the processLearning at this $\mathrm{Al}$ Kaffah. The results of the supervision are reported to the education office of the city of Binjai. The supervision carried out was actually carried out by the managerial supervisory function while the academic and clinical supervisors were more accommodated by the school supervisor from the education office of the city of Binjai. Likewise, performance and what is done as a leader at SMP IT Al Kaffah Binjai must be supervised by the foundation."(Results of interview with $\mathrm{Mr} . \mathrm{H}$. Hanafiah I, S.Pd., MM, January 5, 2021).

Meanwhile added by the Deputy Principal for Curriculum 
during the interview, it was said that:

"In some technical aspects of implementing the curriculum, I am responsible for supervising several learning documents before the supervisor from the city education office comes to school. What I have to supervise is how educators make planning programs to the implementation of learning in the classroom and make assessments as a series of learning activities. The process of supervision is not intended to show superiority but to find solutions if there are obstacles in the learning process. The principal has the responsibility to oversee the implementation of the curriculum, especially in the process of improving the quality of learning, because he will report to the foundation regarding our performance as deputy principals."(Results of interview with Mrs. Delina Anggraini, S.Pd., January 6, 2021).

Furthermore, the concept map of supervision to improve the quality of learning at SMP IT Al Kaffah Binjai is shown in Figure 3.

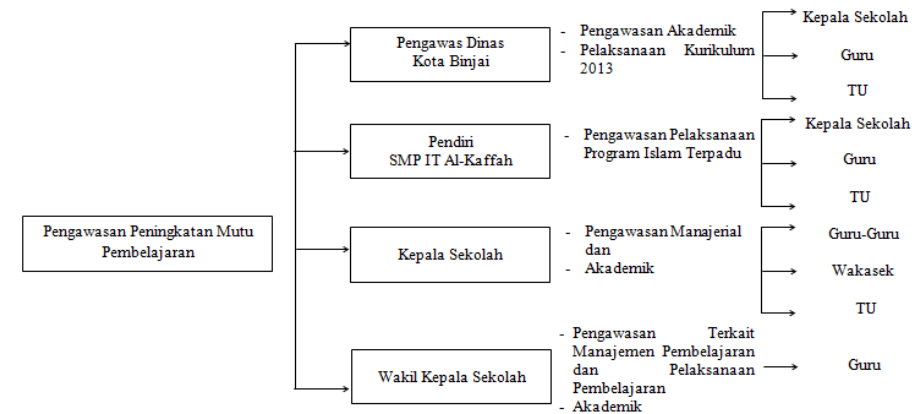

Figure 3. Concept Map of Learning Quality Improvement Supervision

The role of supervisors from the education office, foundations, school principals, and vice principals is to lead to an increase in teacher competence, implementation of programs/activities, improvement of infrastructure facilities, and others, in order to realize the quality of education and learning (Andriana, 2015).

This is supported by the guest list documentation data obtained from the school, regarding a visit from the supervisor to SMP IT Al Kaffah Binjai. The visit is carried out to carry out supervision or supervision of both academic programs, student affairs, and infrastructure.

Based on the interview, observation, and documentation data above, it is concluded that the supervision at SMPIT Al Kaffah Binjai is carried out by the foundation, the education 
supervisor from the service, and managerially is carried out by the principal assisted by the vice principal of the curriculum. Especially in the field of learning, supervision of teachers who carry out the learning process is carried out at the beginning of the learning year from planning documents to learning activities and student assessment activities as part of the supervisory task by the vice principal in the curriculum field.

\section{Likewise,} school supervisors from the Binjai City service always carry out routine supervision programs to schools. As an integrated Islamic school, SMP IT Al Kaffah Binjai contains three programs, namely regular programs, IT programs and selfdevelopment programs, inherent supervision is also carried out by school stakeholders, especially on IT programs that have been established.

\section{CONCLUSION}

Based on the results of the study, it was concluded that efforts to improve the quality of learning at SMP IT Al Kaffah were managed well and effectively. This is viewed from (1) planning, including the formation of a curriculum development team, managing learning activities according to the national education calendar, ensuring teachers create learning programs, planning for student recruitment preparations (new students or transfer students), school orientation and additional programs, and preparation learning planning documents; (2) organizing, including a structured delegation of school organization, starting from the founder delegating it to the foundation, the foundation delegating it to the principal, as well as the principal who is assisted by representatives, teachers and education staff; (3) implementation, including the process of interaction between, teachers and students as well as learning facilities; and (4) supervision, including internal supervision (principal) and external supervision (supervisor from the Binjai City Education Office), which oversees the academic and managerial aspects of the school.

\section{BIBLIOGRAPHY}

Alfiansyah, M., et.al. (2020). "Kebijakan Internal Madrasah dalam Meningkatkan Mutu Pendidikan di MI Nurul Ummah Kotagede Yogyakarta" MAGISTRA: Media Pengembangan Ilmu Pendidikan Dasar dan Keislaman, 11(1). https://www.publikasiilmiah.unwaha 
s.ac.id/index.php/MAGISTRA/articl

e/viewFile/3460/3192.

Amrullah. (2015). "Sekolah Islam Terpadu: Sebuah Tinjauan Kritis" Jurnal Tadrib, $\quad$ 1(1). http://jurnal.radenfatah.ac.id/index.p $\mathrm{hp} /$ Tadrib/article/view/1033.

Andriana, Karmila. (2015). "Urgensi Perencanaan Pembelajaran Bahasa Arab dalam Pendidikan di Sekolah" Prosiding Konferensi Nasional Bahasa Arab (Konasbara), 1. http://prosiding.arab-

um.com/index.php/konasbara/article/ view/22.

Asmara, Yeni \& Dina Sri Nindianti. (2019). “Urgensi Manajemen Kelas untuk Mencapai Tujuan Pembelajaran" Sindang: Jurnal Pendidikan Sejarah dan Kajian Sejarah, 1(1). https://ojs.stkippgrilubuklinggau.ac.id/index.php/JS/artic le/view/192.

Assingkily, Muhammad Shaleh \& Mesiono. (2019). "Karakteristik Kepemimpinan Transformasional di Madrasah Ibtidaiyah (MI) serta Relevansinya dengan Visi Pendidikan Abad 21" Manageria: Jurnal Manajemen Pendidikan Islam, $\quad 4(1)$. http://202.0.92.5/tarbiyah/manageria/ article/download/2475/1648.
Azra, Azyumardi. (2002). Paradigma Baru Pendidikan Nasional, Rekontruksi dan Demokratisasi. Jakarta: Penerbit Buku Kompas.

Creswell, John W. (2009). Research Design Qualitative, Quantitative, and Mixed Methods Approaches. California: SAGE Publications, Inc.

Danim, Sudarwan. (2006). Visi Baru Manajemen Sekolah, dari Unit Birokrasi ke Lembaga Akademis. Jakarta: Bumi Aksara.

Darussalam. (2020). "Urgensi Pengawasan Sekolah dalam Meningkatkan Kinerja Guru Pendidikan Agama Islam di SMPN Serbajadi Aceh Timur" Al-Qiraah, 14(2). http://jurnal.kopertais5aceh.or.id/inde x.php/al-qiraah/article/view/124.

Dryden, Gordon \& Jeannette Vos. (2001). The Learning Revolution: To Change The Way World Learns. USA: Network Educational Press.

Fattah, Nanang. (2011). Landasan Manajemen Pendidikan. Bandung: PT. Remaja Rosdakarya.

Lubis, Masruroh, et.al. (2020). "Pembelajaran Pendidikan Agama Islam Berbasis E-Learning (Studi Inovasi Pendidik MTs. PAI Medan di Tengah Wabah Covid-19)" Fitrah: Journal of Islamic Education, 1(1). http://jurnal.staisumateramedan.ac.id/index.php/fitrah/article/v 
iew/1.

Mulyasana, Dedi. (2012). Pendidikan

Bermutu dan Berdaya Saing.

Bandung: PT Remaja Rosdakarya.

Nadlir, M. (2013). "Perencanaan Pembelajaran Berbasis Karakter" Jurnal Pendidikan Agama Islam, 1(2): 338-352.

https://doi.org/10.15642/jpai.2013.1.

2.338-352.

Nurlaila. (2018). "Urgensi Perencanaan Pembelajaran dalam Peningkatan Profesionalisme Guru" Sustainable: Jurnal Kajian Mutu Pendidikan, l(1).

http://jurnal.kopertais5aceh.or.id/inde x.php/al-qiraah/article/view/124.

Prabowo, Sugeng Listyo. (2010). "Perencanaan Pembelajaran pada Bidang Studi, Bidang Studi Tematik, Muatan Lokal, Kecakapan Hidup, Bimbingan dan Konseling" UIN Maliki Press. http://repository.uinmalang.ac.id/1616/.

Rahayu, Galih Dani Septiyan \& Dida Firmansyah. (2018). "Pengembangan Pembelajaran Inovatif Berbasis Pendampingan Bagi Guru Sekolah Dasar" Abdimas Siliwangi, 1(1). https://www.journal.ikipsiliwangi.ac. id/index.php/abdimassiliwangi/article/view/36.
Sallish, Edward. (2010). Total Quality Management in Education. Yogyakarta: IRCiSoD.

Sugiyono. (2010). Metode Penelitian Kuantitatif, Kualitatif dan $R \& D$. Bandung: Alfabeta.

Syafarudin. (2002). Manajemen Mutu Terpadu dalam Pendidikan. Jakarta: Grasindo.

Syafaruddin, et.al. (2020). "Manajemen Pembelajaran Pendidikan Agama Islam di SDIT Bunayya Pandan Kabupaten Tapanuli Tengah" AULADUNA: Jurnal Pendidikan Dasar Islam, $\quad 7(1)$. http://repository.uinsu.ac.id/id/eprint/ 8966.

Terry \& Reice. (1996). Dasar-dasar Manajemen, terj. G.A Ticoalu. Jakarta: Bumi Aksara. 